\title{
ORIENTASI PERAN EGALITER, KESEIMBANGAN KERJA-KELUARGA DAN KEPUASAN KELUARGA PADA PEREMPUAN YANG BERPERAN GANDA
}

\author{
Hilwa Anwar \\ Fakultas Psikologi Universitas Negeri Makassar \\ Email: hilwa.resdianto@gmail.com
}

\begin{abstract}
Family and work are two important domains that can't be separated from the life of women with dual role. In this research, work-family study focused on the characteristics of family domain and family satisfaction as the output. Women's perception of family gender roles and work family balance is assumed to have an influence on family satisfaction. Therefore, this research aims to examine the relationship between gender role orientation of family, and work-family balance with family satisfaction of women with dual role. Respondent of this research is 108 women who had married and working in the formal sector, with non-probability sampling as the sample taking technique. Data collection method that is used in this study is a scale and processed by using path analysis. Based on the analysis found that there is a positive relationship between egalitarian gender roles orientation with family satisfaction through work-family balance, and its effective contribution is $18.9 \%$.
\end{abstract}

Key words: family satisfaction, work family balance, orientation of egalitarian role, women with dual role

\begin{abstract}
Abstrak
Keluarga dan pekerjaan merupakan dua domain penting yang tidak dapat dipisahkan dari kehidupan perempuan yang berperan ganda. Dalam penelitian ini, kajian kerja-keluarga difokuskan pada karakteristik dari domain keluarga, keseimbangan kerja-keluarga serta kepuasan keluarga sebagai keluarannya. Persepsi perempuan terhadap peran gender dalam keluarganya dan keseimbangan dalam menjalankan peran kerja-keluarga diasumsikan memiliki pengaruh terhadap kepuasan keluarga. Oleh karena itu, penelitian ini bertujuan untuk menguji hubungan orientasi gender dalam keluarga dengan keseimbangan kerjakeluarga dan kepuasan keluarga pada perempuan yang berperan ganda. Subjek penelitian ini adalah 108 perempuan yang sudah berkeluarga dan bekerja di sektor formal. Metode pengumpulan data yang digunakan dalam penelitian ini adalah berupa skala dan diolah dengan menggunakan analisis jalur. Berdasarkan hasil analisis ditemukan bahwa orientasi peran gender keluarga yang egalitarian memiliki hubungan positif dengan keseimbangan kerja-keluarga. Dari hasil analisis jalur diketahui bahwa terdapat hubungan langsung antara orientasi peran gender keluarga yang egalitarian dengan kepuasan keluarga melalui keseimbangan kerja-keluarga, dengan sumbangan efektif sebesar 18,9\%.
\end{abstract}

Kata-kata kunci: Kepuasan Keluarga, Keseimbangan Kerja-Keluarga, Orientasi Peran Egaliter, Perempuan yang Berperan Ganda.

$\mathrm{P}$

erubahan sosio-demografis yang terjadi di seluruh bangsa di dunia mempengaruhi timbulnya pergeseran yang signifikan pada kecenderungan tenaga kerja yang sebelumnya didominasi oleh laki-laki. Menurut Watanabe, Takahashi dan Minami (Earley \& 
Erez, 1997) modernisasi ekonomi dan teknologi telah menciptakan lapangan kerja yang membutuhkan kontribusi perempuan lebih besar daripada sebelumnya.

Peningkatan partisipasi perempuan yang berkeluarga dalam dunia kerja seharusnya sejalan dengan peningkatan kesejahteraan pada perempuan, mengingat sejumlah literatur menunjukkan kombinasi peran dalam pekerjaan dan keluarga pada dasarnya merupakan kombinasi yang kondusif bagi kesehatan dan kesejahteraan (well-being) perempuan (Kousha \& Mohseny, 1997). Hal yang sama juga diungkapkan oleh Kessler dan MacRae (Kousha \& Mohseny, 1997), bahwa perempuan yang menikah dan bekerja menunjukkan kesehatan mental yang lebih baik dibandingkan perempuan yang hanya memilih sebagai ibu rumah tangga. Di sisi lain, sejumlah penelitian yang menelaah isu pekerjaan dan keluarga, menunjukkan bahwa perempuan seringkali dilaporkan mengalami tingkat stres, burmout dan depresi yang lebih tinggi dibandingkan laki-laki (Duxbury \& Higgins, 1991; O'Laughlin \& Bischoff, 2005; Barette, 2006). Jumlah ini selalu mengalami peningkatan setiap tahunnya dan sebagian besar dialami oleh perempuan yang berperan ganda (Barrette, 2006).

Tantangan dan hambatan yang dihadapi perempuan dalam usahanya untuk bekerja dan mencapai karir di luar rumah cenderung lebih kompleks dibandingkan laki-laki. Perempuan peran ganda dihadapkan pada tingginya tekanan baik dari domain kerja maupun dari domain keluarga. Jungkir-balik antara peran kerja dan keluarga merupakan 'makanan' sehari-hari perempuan yang berperan ganda. Keluhan fisik dan psikis seperti kesehatan yang rendah dan mudah mengalami depresi merupakan dampak negatif akibat tekanan peran dalam pekerjaan dan keluarga (Frone, Russel \& Cooper, 1992). Sementara, kesehatan mental dan fisik yang baik merupakan syarat agar mereka dapat berfungsi secara penuh dalam aktivitas sehari-hari mereka.

Secara tradisional, terdapat penekanan masyarakat yang berbeda pada peran laki-laki dan perempuan. Laki-laki berperan sebagai provider atau pencari nafkah, sementara perempuan bertanggung jawab atas pemeliharaan keluarga dan perawatan rumah (Gutek dkk, 1991). Ketika perempuan bekerja untuk mencukupi kebutuhan keluarga, kewajiban-kewajiban tadi masih tetap ditanggungnya. Fenomena ini juga tampak pada rumah tangga dimana istri menghasilkan uang lebih besar dibandingkan dengan suami maupun pada rumah tangga dimana sang suami tidak bekerja. Dengan kondisi tersebut, perempuan yang berperan ganda lebih cenderung sulit menyeimbangkan peran kerja dan keluarganya. Gutek, Searle dan Klepa (1991) bahkan menyimpulkan perempuan yang berperan ganda pada dasarnya melakukan dua pekerjaan full time sekaligus. Dari sejumlah pemaparan di atas, peran ganda perempuan dapat dipahami sebagai dualisme peran pada perempuan yaitu peran keluarga dan peran kerja yang dijalankan secara bersamaan. Terkait dengan peran gandanya, maka kepuasan hidup perempuan peran ganda khususnya kepuasan keluarga menjadi menjadi penting untuk dikaji.

Kepuasan keluarga merupakan bentuk kepuasan individu yang berkaitan dengan domain dan permasalahan keluarga, antara lain peran sebagai orangtua, kedekatan dengan keluarga dan permasalahan yang timbul dalam keluarga tidak terlalu menimbulkan tekanan (Duxbury \& Higgins, 1991). Secara operasional, menurut Barraca dkk. (2000), kepuasan keluarga dapat didefinisikan sebagai sejumlah perasaan yang memenuhi diri subjek ketika berinteraksi, baik secara verbal maupun fisik, dengan anggota keluarga dalam keluarga.

Sementara menurut Ford, Heinen dan Langkamer (2007), konsep yang bersifat general dibutuhkan untuk mengetahui tingkatan kepuasan keluarga yang direfleksikan oleh seseorang. Kepuasan keluarga dapat didefinisikan sebagai kepuasan terhadap kehidupan keluarganya secara global ataupun kepuasan terhadap aspek-aspek dalam kehidupan keluarganya, antara lain seperti kepuasan marital dan kepuasan dalam perawatan anak. Carver dan Jones (1992) dan Olson (Barraca dkk, 2000) menggambarkan 
kepuasan keluarga sebagai dinamisasi yang ada dalam keluarga dan meliputi tiga faktor dasar, yaitu: (1) Kohesivitas, yaitu ikatan emosional yang terbentuk antara anggota keluarga, (2) Adaptabilitas yaitu fleksibilitas dalam aturan, peran dan distribusi kekuasaan yang ada pada satu keluarga dan (3) Komunikasi yang terjalin dalam keluarga.

Dalam kajian ini, kepuasan keluarga dapat dipahami sebagai sikap atau keadaan emosi positif individu terhadap kehidupan keluarga dan peran keluarga yang dijalaninya. Indikator kepuasan keluarga dalam penelitian ini adalah 1) kohesivitas keluarga, 2) komunikasi yang terjalin dalam keluarga, dan 3) adaptabilitas terhadap peran dalam keluarga, yaitu peran marital dan peran parental.

Keseimbangan dalam menjalankan peran kerja dan peran keluarga menjadi kunci penting untuk memperoleh kepuasan pada perempuan yang berperan ganda. Keseimbangan kerja-keluarga umumnya didefinisikan sebagai equilibrium atau keseimbangan sebagai bentuk harmonisasi dalam kehidupan (Hudson, 2005). Menurut Duxbury \& Higgins (1991), keseimbangan kerja-keluarga dalam adalah suatu fenomena perseptual yang ditandai dengan munculnya perasaan telah mencapai resolusi yang memuaskan terhadap berbagai tuntutan peran baik dalam domain keluarga maupun pekerjaan. Sementara menurut Durham (2007) mendefinisikan keseimbangan kerja-keluarga sebagai bentuk harmonisasi dan integrasi yang bersifat holistik antara kerja dan non kerja (rumah).

Sementara pengertian keseimbangan kerja-keluarga menurut Clark (Desrochers \& Sargent, 2004) mengacu pada kepuasan dan good functioning baik pada domain kerja maupun keluarga dengan konflik peran yang minimal. Friedman \& Greenhaus, (2000), mengemukakan bahwa keseimbangan kerjakeluarga tergantung oleh kemampuan seseorang untuk membagi waktu dan perhatiannya terhadap peran-perannya, baik peran kerja maupun peran keluarga. Karena itu aspek-aspek dalam keseimbangan kerjakeluarga meliputi dua hal. Pertama, waktu dan atensi (energi) terhadap masing-masing peran. Kedua, integrasi tuntutan peran kerja dan keluarga.

Berdasarkan berbagai pemahaman di atas, pengertian keseimbangan kerja-keluarga dalam kajian ini dapat didefinisikan sebagai pemenuhan peran kerja dan peran keluarga secara seimbang yang disesuaikan dengan sumber daya yang dimiliki, sehingga terjalin interaksi yang harmonis antara domain kerja dan domain keluarga. Aspek-aspek yang digunakan dalam penelitian ini mengacu pada (1) Waktu, yaitu pembagian sejumlah waktu untuk peran kerja maupun keluarga., (2) Atensi, yaitu pembagian energi/perhatian dan keterlibatan terhadap peran kerja maupun peran keluarga dan (3) Integrasi peran kerja dan keluarga, yaitu interaksi positif peran kerja terhadap keluarga dan juga sebaliknya peran keluarga terhadap kerja.

$$
\text { Selain keseimbangan dalam }
$$
menjalankan peran di domain kerja dan keluarga, karakter dari masing-masing domain menjadi kunci penting untuk memperoleh kepuasan pada perempuan yang berperan ganda. Dalam domain keluarga, kecenderungan keluarga dengan dual-earner couple pada saat ini membuat kepuasan keluarga pada perempuan berperan ganda seringkali dihubungkan dengan peran tradisional sebagai ibu dan isteri, yang bertanggung jawab terhadap wilayah domestik rumah tangga (Scanzoni \& Scanzoni, 1981). Pembagian peran dalam pola tradisional cenderung bersifat dikotomi dengan menempatkan laki-laki sebagai pencari nafkah dan perempuan bertanggung jawab terhadap urusan domestik rumah tangga (Supriyantini, 2002). Peningkatan tanggung jawab dalam domain pekerjaan tanpa diikuti penurunan tanggung jawab dalam domain keluarga membuat perempuan mengalami beban yang berlebih dan sulit menyeimbangkan perannya pada kedua domain tersebut (Duxbury \& Higgins, 1991). Sebaliknya dalam keluarga yang mengembangkan peran gender egaliter, maka 
peran kerja dan keluarga bukanlah suatu yang bersifat dikotomi. Keluarga yang berpandangan egaliter, cenderung meminimalisasikan pemisahan peran yang berdasarkan gender, sehingga lebih mudah melakukan negosiasi peran dan berbagi tanggung jawab dalam pekerjaan rumah tangga (Judge \& Livingston, 2008).

Judge \& Livingstone (2008) mendefinisikan peran gender sebagai keyakinan seseorang mengenai peran yang sesuai berdasarkan gendernya. Sementara dalam teori peran gender yang dikemukakan oleh Gutek dkk. (1991) dan teori peran sosial (Eagly, dalam King, 2005), keduanya menggambarkan terdapat polarisasi peran berdasarkan gendernya. Menurut Eagly (King, 2005), perempuan dianggap lebih mampu mengembangkan perilaku-perilaku sosial sementara laki-laki dianggap lebih sering mengembangkan perilaku-perilaku yang berorientasi terhadap kerja. Perempuan juga diidentifikasikan dengan peran keluarga dan dianggap sesuai untuk memenuhi peran dalam wilayah domestik.

Menurut Larsen \& Long (1988), berdasarkan gendernya, orientasi peran perempuan dan laki-laki dibedakan atas dua perspektif, yaitu peran gender tradisional dan egaliter. Orientasi peran yang tradisional cenderung menekankan pemisahan masingmasing peran secara ideal. Dalam peran gender modern (egalitarian), tidak ada lagi pembagian tugas yang berdasarkan jenis kelamin secara kaku, kedua jenis kelamin diperlakukan sejajar atau sederajat. Orientasi peran egaliter cenderung meminimalisasikan pemisahan peran yang berdasarkan gender. Orientasi peran gender yang dimaksud dalam kajian ini adalah orientasi peran yang egaliter, yaitu sikap yang menekankan nilai-nilai peran gender egaliter atau kesetaraan peran antara laki-laki dan perempuan dalam keluarga. Aspek-aspek yang dianggap lebih sesuai dikembangkan dalam penelitian ini mengacu pada tiga peran, peran marital, peran parental dan peran kerja.

Berdasarkan berbagai uraian di atas, dapat diformulasikan bahwa keluarga dan pekerjaan merupakan dua domain penting yang tidak dapat dipisahkan dari kehidupan perempuan yang berperan ganda. Mereka dihadapkan pada budaya ketimuran Indonesia dengan nilai-nilai patriarki yang kuat tentang peran tradisional perempuan. Orientasi peran egalitarian dalam keluarga diasumsikan sebagai karakteristik dalam domain keluarga yang dapat mempengaruhi kepuasan keluarga pada perempuan. Namun demikian, pencapaian kepuasan keluarga sangat ditentukan oleh keseimbangan dalam menjalankan peran kerja dan keluarga. Keseimbangan kerja-keluarga merupakan prediktor yang mempengaruhi secara langsung kepuasan kerja dan keluarga pada perempuan yang berperan ganda. Rumusan masalah terkait dengan hal tersebut adalah "apakah ada hubungan langsung maupun tidak langsung antara orientasi peran egaliter dengan keseimbangan kerja-keluarga dan kepuasan keluarga pada perempuan yang berperan ganda". Kajian empirik ini diharapkan dapat mengakomodir kesenjangan antara tuntutan peran dalam pekerjaan dan keluarga dengan keterbatasan perempuan. Untuk selanjutnya diharapkan dapat menjadi landasan kebijakan kerja dalam mengatasi permasalahan yang ditimbulkan oleh gesekan antara pekerjaan dan keluarga.

Hipotesis yang diajukan dalam kajian ini adalah ada hubungan positif antara orientasi peran gender keluarga dengan kepuasan keluarga, baik secara langsung maupun tidak langsung yaitu melalui keseimbangan kerjakeluarga.

\section{METODE}

Pengambilan data dilakukan di kota Makassar dan melibatkan 108 responden yang telah memenuhi syarat dengan sejumlah kriteria yang ditetapkan, yaitu (1) perempuan yang sudah menikah (berkeluarga) dan bekerja fulltime di sektor formal, yaitu pegawai negeri, karyawan BUMN dan perusahaan swasta, (2) pendidikan minimal Diploma, (3) memiliki anak minimal satu orang berusia di bawah enam tahun, dan (4) memiliki pasangan/suami yang juga bekerja, serta tinggal serumah dengan suami dan anak. 
Metode pengumpulan data dalam penelitian ini menggunakan skala. Butir-butir pernyataan dalam skala ini menggunakan empat alternatif jawaban, yaitu Sangat Sesuai (SS), Sesuai (S), Tidak Sesuai (TS) dan Sangat Tidak Sesuai (STS). Skala ini juga terdiri atas butir-butir pernyataan yang bersifat mendukung (favorable) dan tidak mendukung (unfavorable). Pemberian skor dilakukan berdasarkan sifat butir dan angka skor berkisar antara 1 sampai dengan 4. Sebelum skala digunakan untuk pengumpulan data penelitian, terlebih dahulu skala diujicobakan kepada responden $(n=82)$ untuk kemudian diuji validitas dan reliabilitasnya. Skala yang digunakan dalam penelitian ini adalah sebagai berikut:

Skala Kepuasan Keluarga. Skala ini bertujuan untuk mengukur tingkat kepuasan keluarga yang dialami oleh perempuan yang berperan ganda. Penyusunan skala ini mengacu pada indikator kepuasan keluarga yang dikembangkan oleh Carver dan Jones (1992) dan Olson (Barraca dkk, 2000), yaitu: (1) Kohesivitas keluarga, (2) Komunikasi dalam keluarga, dan (3) Adaptabilitas terhadap peran keluarga. Validitas dan reliabilitas skala menghasilkan 7 butir valid ( $\mathrm{r}$ berkisar 0,339 hingga 0,642) dengan reliabilitas sebesar 0,861.

Skala Keseimbangan Kerja-Keluarga. Skala ini bertujuan untuk mengukur tingkat keseimbangan pada perempuan yang berperan ganda dalam menjalankan peran kerja dan peran keluarga. Penyusunan skala ini mengacu pada aspek-aspek yang dikembangan oleh Friedman dan Grenhaus (2000), yaitu: (1) Waktu, (2) Atensi, dan (3) Integrasi peran kerja dan peran keluarga. Validitas dan reliabilitas skala menunjukkan 10 butir valid ( $\mathrm{r}$ berkisar 0,324 hingga 0,731 ) dengan nilai reliabilitas sebesar 0,851 .

\section{Skala Orientasi peran gender} keluarga. Skala ini bertujuan untuk mengukur persepsi perempuan yang berperan ganda terhadap orientasi peran gender, yaitu tingkatan egaliter dalam keluarganya. Penyusunan skala ini mengacu pada konsep yang dikemukakan oleh King dan King (White, 2008). Aspekaspeknya adalah, (1) peran marital, (2) peran parental, dan (3) peran kerja. Validitas dan reliabilitas skala menghasilkan 12 butir skala valid ( $\mathrm{r}$ berkisar 0,353 hingga 0,618), dengan nilai reliabilitas akhir sebesar 0,843 .

\section{HASIL DAN PEMBAHASAN}

Uji hipotesis dilakukan dengan menggunakan analisis jalur, melalui bantuan SPSS version 15.0 for windows. Adapun hasil analis menunjukkan tidak terdapat hubungan langsung yang signifikan antara orientasi peran gender dengan kepuasan keluarga $(r=0,102$ dengan $p=0,296, p>0,05)$. Dari uji parsial diketahui bahwa terdapat hubungan positif yang signifikan antara orientasi peran gender dengan keseimbangan kerja-keluarga, dengan nilai $\mathrm{p}=0,004(\mathrm{p}<0,01)$, begitu juga hubungan antara keseimbangan kerja-keluarga dengan kepuasan keluarga, terdapat hubungan yang positif yang signifikan dengan nilai $r=0,671$ $(p=0,001 ; p<0,01)$. Besar sumbangan masingmasing adalah sebagai berikut: Besar sumbangan pengaruh orientasi peran gender keluarga terhadap keseimbangan kerja-keluarga adalah sebesar 28\%, keseimbangan kerjakeluarga memiliki sumbangan pengaruh sebesar 67,5\% terhadap kepuasan keluarga. Sementara pengaruh orientasi peran gender terhadap kepuasan keluarga, melalui keseimbangan kerja keluarga memberikan efek sebesar 18,9\%. Dengan demikian, hipotesis: "ada hubungan positif antara orientasi peran gender keluarga dengan kepuasan keluarga melalui keseimbangan kerja-keluarga", diterima.

Hasil analisis dalam penelitian ini mengindikasikan orientasi peran gender keluarga yang egaliter memiliki hubungan positif yang sangat signifikan dengan keseimbangan kerja-keluarga. Besar sumbangan pengaruh orientasi peran gender keluarga terhadap keseimbangan kerja-keluarga adalah sebesar 28\%, sedangkan sisanya dijelaskan oleh faktor lain. Hasil ini konsisten dengan kajian yang dilakukan oleh Grzywacs 
\& Carlson (2007) dan Aryee dkk (2005), yang menyimpulkan bahwa pola keluarga yang terbuka, sensitif dan penuh dukungan berkorelasi dengan dimensi keseimbangan kerja-keluarga. Menurut Grzywacs \& Carlson (2007), keseimbangan kerja-keluarga dapat tercipta melalui respon yang ditunjukkan oleh keluarga, terutama pasangan, terhadap peran kerja seseorang. Salah satunya terlihat dari kesediaan dalam berbagi peran dalam keluarga.

Khusus pada perempuan yang berperan ganda, adanya keterbatasan antara lain dalam hal waktu, energi dan ideologi peran tradisional, menyulitkan mereka untuk menjalankan kedua perannya secara optimal. Oleh karena itu, faktor dari domain keluarga seperti orientasi peran gender keluarga egalitarian, menjadi faktor-faktor yang cukup penting bagi perempuan yang berperan ganda dalam menjalankan peran kerja dan peran keluarga secara seimbang.

Dalam keluarga yang cenderung menerapkan orientasi peran gender egaliter, pembagian peran kerja dan peran keluarga menjadi lebih fleksibel. Anggota keluarga, terutama suami, lebih mampu menyesuaikan diri dengan situasi yang menuntut karakteristik feminin seperti halnya pembagian pekerjaan rumah tangga dan pengasuhan anak. Kondisi ini tidak saja mengandung arti beban kerja rumah tangga menjadi lebih ringan, namun juga menunjukkan adanya dukungan keluarga terhadap peran kerja yang dilakukan oleh perempuan, sehingga dapat menjalankan peran kerja dan peran keluarganya secara seimbang.

Sehubungan dengan hubungan antara orientasi peran gender keluarga dengan kepuasan keluarga melalui keseimbangan kerja-keluarga, dari hasil analisis ditemukan ada hubungan antara orientasi peran gender egalitarian dengan kepuasan keluarga melalui keseimbangan kerja-keluarga. Hasil analisis juga menunjukkan orientasi peran gender egalitarian tidak berkorelasi secara langsung dengan kepuasan keluarga, sementara keseimbangan kerja-keluarga menunjukkan korelasi yang signifikan dengan kepuasan keluarga. Besar sumbangan efektif orientasi peran gender egalitarian terhadap kepuasan keluarga dengan melalui keseimbangan kerjakeluarga adalah $18,9 \%$. Sementara pengaruh keseimbangan kerja-keluarga terhadap kepuasan keluarga memberikan sumbangan efektif sebesar $67,5 \%$.

Hasil ini membuktikan asumsi bahwa pencapaian kepuasan keluarga pada perempuan yang berperan ganda dipengaruhi secara langsung oleh keseimbangan kerja-keluarga. Sementara terciptanya keseimbangan dalam menjalankan peran kerja-keluarga dipengaruhi oleh karakteristik dari masing-masing domain, salah satunya dari domain keluarga, yaitu orientasi peran gender egaliter. Oleh karena itu, hubungan antara orientasi peran gender egaliter dengan kepuasan keluarga merupakan hubungan yang dimediasi oleh faktor keseimbangan kerja-keluarga.

\section{KESIMPULAN DAN SARAN}

Berdasarkan hasil dan diskusi penelitian, maka dapat disimpulkan terdapat hubungan positif antara orientasi peran gender keluarga dengan kepuasan keluarga melalui keseimbangan kerja-keluarga, sementara hubungan langsung antara orientasi peran gender keluarga dengan kepuasan keluarga tidak menunjukkan nilai korelasi yang signifikan. Oleh karena itu, disarankan organisasi diharapkan dapat menciptakan lingkungan kerja yang bersifat familiy friendly sehingga karyawannya, terutama perempuan yang berperan ganda mampu menjalankan multi perannya secara seimbang. Sementara untuk keluarga diharapkan dapat terbuka untuk melakukan negosiasi ulang dalam hal ekspetasi peran gender dalam keluarga. Untuk penelitian selanjutnya, dikarenakan penelitian ini lebih mengacu pada faktor-faktor eksternal, maka faktor disposisi individu dan karakter perempuan juga perlu dikaji. Sehubungan dengan subjek penelitian, peneliti selanjutnya juga perlu memperhatikan level jabatan maupun sifat kerja perempuan yang berperan ganda, seperti pekerjaan profesional dan pekerjaan administratif. 


\section{DAFTAR RUJUKAN}

Aryee, S., Srinivas, E.S., \& Tan, H.H. 2005. Rhythms of life: antecedents and outcomes of work-family balance in employed parents. Journal of Applied Psychology, 90(1). 132-146.

Barraca, J., Yarto, L.L., \& Olea, J. 2000. Psychometric properties of new family life satisfaction scale. European Journal of Psychological Assessment, 16(2). 98-106.

Barrette, J. 2006. Work/Family Balance: What Do We Really Know? Canada: Vanier Institute of The Family.

Carver, M.D., \& Jones, W.H. 1992. The family satisfaction scale. Social Behavior and Personality, 20. 71-84.

Desrochers, S. \& Sargent, L.D. 2004. Boundary/Border Theory and workfamily integration. Organizational Management Journal, 1(1), 40-48.

Duxbury, L.E., Higgins, C.A. 1991. Gender differences in work-family conflict. Journal of Applied Psychology, 76(1). 60-74.

Earley, P.C., Erez, M. (1997). New Perspectives on International Industrial/ Organizational Psychology. San Fransisco: The New Lexington Press

Ford, M.T., Heinen, B.A. \& Langkamer, K.L. 2007. Work and family satisfaction and conflict: a meta analysis of crossdomain relations. Journal of Applied Psychology, 92(1). 57-80.

Friedman, S.D., \& Greenhaus, J.H. 2000. Work and Family - Allies or Enemies? New York: Oxford University Press.

Frone, M.R., Russel, M., Cooper, M.L. 1992. Antecedents and outcomes of workfamily conflict: testing a model of the work-family interface. Journal of Applied Psychology, 77(1). 65-78.
Grzywacz, J.G., \& Carlson, D.S. 2007. Conceptualizing work-family balance: implications for practice and research. Advances in Developing Human Resources, 9(4). 455-471. Diakses tanggal 19 Juni 2009 dari http://adh.sagepub.com/cgi/content/ 9/4/455.

Gutek, C.A., Searle, S. \& Klepa, L. (1991). Rational versus gender role explanations for work-family conflict. Journal of Applied Psychology, 76(4), 560-568.

Hudson. 2005. The Case for Work/Life Balance: Closing the Gap between Policy and Practice. NZ: Hudson Highland Group.

Judge, T.A., \& Livingston, B.A. 2008. Is the gap more than gender? a longitudinal analysis of gender, gender role orientation and earnings. Journal of Applied Psychology, 93(5). 994-1012.

King, J.J. 2005. Gender ideology: impact on dual-career couples' role strain, marital satisfaction and life satisfaction. Dissertation. Texas: A\&M University.

Kousha, M., \& Mohseny, N. 1997. Predictors of life satisfaction among urban Iranian women: an exploratory analysis. Social Indicators Research, 40. 329-357.

Larsen, K. S., \& Long, E. 1988. Attitudes toward sex-roles: traditional or egalitarian. Sex Roles, 19.1-12.

O’Laughlin, C.M., Bischoff, L.Y. 2005. Balancing parenthood and academia: work-family stress as influenced by gender and tenure status. Journal of Family Issues, 26(1). 79-106.

Scanzoni, L.D, \& Scanzoni, J. 1981. Men, Women, and Change. USA: McGraw Hill Inc.

Supriyantini, S. 2002. Hubungan antara pandangan peran gender dengan 
62| Talenta, Vol. 1 No. 1

keterlibatan suami dalam kegiatan rumah tangga. Laporan Penelitian (tidak diterbitkan). Medan: Fakultas Kedokkteran USU.

White, A.P. 2008. An examination of Virginia Soil and Water Conservation District employee job satisfaction. Dissertation. Virginia: Virginia Polytechnic Institute and State University. 